\title{
Change at the top for climate panel
}

The Intergovernmental Panel on Climate Change (IPCC) elected new leadership last week in Geneva, Switzerland, unanimously re-electing the Indian economist Rajendra Pachauri as chairman but choosing new heads of the three working groups that coordinate the writing of its massive reports.

The most significant race was for the leadership of Working Group I, which evaluates the basic science of climate change. Swiss climate modeller Thomas Stocker came out ahead after two initial votes narrowed a field of four to him and Francis Zwiers, a senior scientist at the Canadian Centre for Climate Modelling and Analysis in Toronto.

Stocker heads the climate and environmental physics unit at the University of Bern and has been a coordinating lead author in Working Group I during the past two assessments. He sees plenty of work to do in assessing sealevel rise, carbon-cycle feedbacks, and regional impacts. Qin Dahe, who heads the China Meteorological Association, stays on as cochair representing a developing nation.

"The value of the IPCC is utterly dependent on top scientists such as these as co-chairs to lead the assessment process," says Susan Solomon of the US National Oceanic and Atmospheric Administration in Boulder, Colorado, who served as lead co-chair of Working Group I for the most recent assessment in 2007.

Working Group II, which assesses impacts and adaptation, will be chaired by Chris Field, an ecologist who heads the Carnegie Institution's Department of Global Ecology in

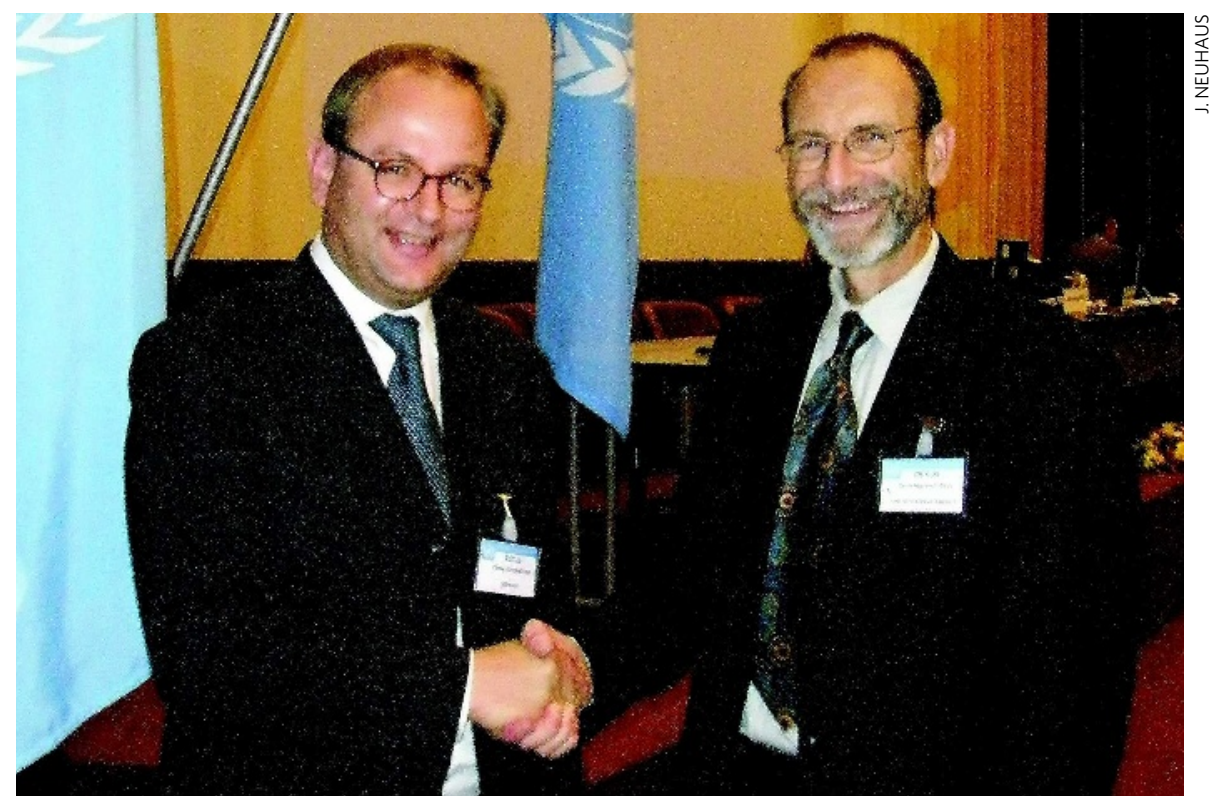

Newly elected co-chairs of IPCC working groups Ottmar Edenhofer (left) and Chris Field.

Stanford, California. His co-chair will be Vicente Barros, an oceanographer at the University of Buenos Aires.

For the next assessment, Field says he wants to further integrate the sciences pertaining to impacts and adaptation. He also wants to drill down to "the levels of processes" instead of just listing the types of changes that can be expected under climate change. He will also push for a separate chapter on oceans to look at acidification, warming and loss of ice cover.

\section{Spending the Nobel prize}

Since winning the Nobel Peace Prize in 2007, the Intergovernmental Panel on Climate Change (IPCC) has had 885,000 Swiss francs (US\$785,000) burning a hole in its pocket.

Now it proposes to put the money into a trust fund, tentatively named the IPCC Bert Bolin Memorial Scholarship Fund, after the Swedish climatologist who was the panel's first chairman and who died on 30 December last year. The fund would support PhD students and postdocs from the developing world.
Organizers expect private donors to supplement the prize money. The IPCC chairman and workinggroup co-chairs will pick scholars, with the aim of building understanding and management of climate change in developing nations, where its impacts are expected to be highest. Saleemul Huq, head of the International Institute for Environment and Development's climatechange programme in London, believes the fund will also benefit the IPCC. "There's still a dearth of qualified scientists in developing countries who can be drawn on as lead authors," he says.

But scholarships are no radical innovation, says Mickey Glantz, director of the Center for Capacity Building, currently at the US National Center for Atmospheric Research in Boulder, Colorado.

"The developing world has a lot of expertise in it, but we keep them in a dependent mode," he says. "We should be fostering south-south connections, not just north-south connections." Anna Barnett
Working Group III, which assesses mitigation options, will be headed by Ottmar Edenhofer, chief economist at the Potsdam Institute for Climate Impact Research in Germany. He says he wants to give business people and policy-makers a larger role and "be a bit more precise" about the advantages, costs and risks of different options.

All the co-chairs support further integration among the three working groups. They differ in their attitude to special reports - targeted assessments to address pressing policy questions. Edenhofer favours their use; Field and Stocker don't emphasize them as much. The panel is currently preparing a special report on renewable energy, and Edenhofer says he has secured an agreement from the German government for additional resources for such purposes.

In a departure forced by a tight vote and procedural complications, Edenhofer will have two co-chairs: Ramón Pichs Madruga, an economist at the Center for Research on the World Economy in Havana, and Youba Sokona, a Malian environmental scientist who heads the Sahara and Sahel Observatory in Tunis.

"It was a political compromise allowing everybody to save face," says new IPCC vicechair Jean-Pascal Van Ypersele, a climatologist at the Catholic University of Louvain, Belgium. "It was not perfect, but it in the end it was accepted by everybody."

Jeff Tollefson 